\title{
AN EFFECT OF CARDIOPROTECTIVE ACTIVITY IN VARIOUS MEDICINAL PLANTS-A REVIEW
}

\author{
VIJAYA NIRMALA R., ABINAYA R. \\ Department of Gunapadam (Pharmacology), Govt Sidhha Medical College, Chennai \\ Email: drvijiguna@gmail.com
}

Received: 14 Nov 2018, Revised and Accepted: 20 Feb 2019

\begin{abstract}
Siddha system of medicines is known for its herbal in origin. Herbal plays a major role in treating acute and chronic diseases. Cardiovascular diseases (CVDs) is the life-threatening disease that contributes a leading cause of death day by day across the world.

A change in lifestyle modification is the one of the risks of CVDs. This review paper attempts to facilitate the cardioprotective activity by providing different types of medicinal plants and its botanical distribution, description, chemical constituents and pharmacological activity. Few important herbs will protect the human being from CVDs and gives health and quality of life. In this paper, the authors explores the effect of cardioprotective activity in medicinal plants as follows, Terminalia chebula (Kadukkai), Piper longum (Thippili), Zingiber officinale (Inji), Tinospora cordifolia (Seenthil), Asparagus racemosus (Thanneervitan), Embelia ribes (Vaaivilangam), Andrographis paniculata (Nilavembu), Nelumbo nucifera (Thaamarai), Allium sativum (Vellaipoondu), Bauhinia variegata (Mantharai).
\end{abstract}

Keywords: Siddha, Cardioprotective plants, Cardiovascular diseases, CVDs

(C) 2019 The Authors. Published by Innovare Academic Sciences Pvt Ltd. This is an open-access article under the CC BY license (http://creativecommons.org/licenses/by/4.0/) DOI: http://dx.doi.org/10.22159/ijcpr.2019v11i2.33019

\section{INTRODUCTION}

Cardiovascular diseases are the major health problem of advanced as well as developing countries of the world [1]. Cardiovascular diseases (CVDs) are the most prevalent cause of death and disability worldwide. CVD, a group of disorders of the heart and the vasculature, includes high blood pressure, coronary heart disease, myocardial infarction, congenital heart defects, cardiac arrhythmias, heart failure and stroke [2].

Cardioprotection includes "all mechanisms and means that contribute to the preservation of the heart by reducing or even preventing myocardial damage". Defining "Cardioprotection" as "preservation of the heart" has all theoretical implications because all adaptive and compensatory mechanisms that directly or indirectly contribute to myocardial preservation have to be classified as "cardioprotective" [3].

Some modern drugs like organic nitrates, calcium channel antagonist and $\beta$-blockers are effective in preventing the heart disorders; their use is often limited because of their side effects and adverse reactivity. So the wide variety of plants and its active principles, with minimal side effects, provide an alternate therapy for heart disease [4]. Nature has been a source of Medicinal treatments for years and plants derived products continue to play an important role in the primary healthcare of about $80-85 \%$ of the world population. A review of such plants with cardioprotective effects was carried out. Several herbs and herbal products have been recommended to promote a healthy heart [5].

\section{Global burden of cardiovascular disease}

The choice of lifestyle, obesity, diabetes mellitus and hypertension are causative factors of cardiovascular diseases. Globally, cardiovascular diseases (CVD) are the number one cause of death and they are projected to remain so. An estimated 17 million people died from cardiovascular disease in 2005 , representing $30 \%$ of all global deaths. If current trends are allowed to continue, by 2030 an estimated 23.6 million people will die from cardiovascular disease [6].

The major risk factors associated with CHD and stroke are tobacco and alcohol abuse, high blood pressure (hypertension), high cholesterol, obesity, physical inactivity, and unhealthy diets contributing to high prevalence across the world [7].
Cardioprotective plants

Botanical name: Terminalia chebula

Tamil name: Kadukkai

Taxonomy

Kingdom: Plantae

Division: Magnoliophyta

Class: Magnoliopsida

Order: Myrtales

Family: Combretaceae

Genus: Terminalia

Species: chebula

\section{Distribution}

Terminalia chebula occurs naturally from the sub-Himalayan region of Nepal and northern India, through India to Sri Lanka, Burma, Thailand, Indo-China and southern China. It has been introduced to Singapore, where it failed, but it was planted successfully in the botanical garden in Bogor, Java. It was also introduced to Peninsular Malaysia [8].

\section{Description}

A medium-sized, up to $25 \mathrm{~m}$ tall, deciduous tree of variable appearance, with a usually short cylindrical bole of 5-10 m length, 60-80 cm in diameter at breast height; crown rounded, with spreading branches; bark dark brown, usually longitudinally cracked with woody scales; branchlets rusty-villous or glabrescent. Leaves alternate or opposite, thin-coriaceous, ovate or elliptic-ovate, 7-12 $\mathrm{cm} \times$ 4-6.5 $\mathrm{cm}$, rounded at base, obtuse to subacute at apex, entire, pubescent beneath; petiole up to $2 \mathrm{~cm}$ long, provided with 2 glands at the base of the leaf blade. Flowers in auxiliary $5-7 \mathrm{~cm}$ long spikes, simple or sometimes branched, about $4 \mathrm{~mm}$ across, yellowish-white and unpleasantly scented; calyx 5-lobed, corolla absent; stamens 10 , exerted; ovary inferior, 1-celled. Fruit an ovoid or oblong-ellipsoid drupe, $2.5-5 \mathrm{~cm}$ long, faintly 5-angular, yellow to orange-brown when ripe, glabrous [9]. 


\section{Part used}

Fruit rind

\section{Major chemical constituents}

Tannin, gallic acid, mucilage, chebulinic acid [10]

\section{Cardioprotective activity}

Terminalia chebula extract pretreatment was found to ameliorate the effect of isoproterenol on lipid peroxide formation and retained the activities of the diagnostic marker enzymes in isoproterenolinduced myocardial damage in rats [11]

\section{Botanical name: Piper longum}

Tamil name: Thippili

\section{Taxonomy}

Kingdom: Plantae

Division: Magnoliophyta

Class: Magnoliopsida

Order: Piperales

Family: Piperaceae

Genus: Piper

Species: longum

\section{Distribution}

The plant grows in evergreen forests of India and is cultivated in Assam, Tamil Nadu, and Andhra Pradesh. Long pepper is cultivated on a large scale in limestone soil and in heavy rainfall areas where relative humidity is high.

\section{Description}

Piper longum is a small shrub with a large woody root and numerous creeping, jointed stems that are thickened at the nodes. The leaves are alternate, spreading, without stipules and with blades varying greatly in size. The lowest leaves are 5-7 cm long, whereas, the uppermost are $2-3 \mathrm{~cm}$ long. Flowers grow in solitary spikes. The fruits, which grow in fleshy spikes $2.5-3.5 \mathrm{~cm}$ long and $5 \mathrm{~mm}$ thick, are oblong, blunt, and blackish-green. The mature spikes are collected and dried as the commercial form of pippali, and the root radix is known as pippalimula. There are three grades of piplamul: grade I with thick roots and underground stems fetch a higher price than grade II or III, which consist of thin roots, stems, or broken fragments. The commercial drug consists almost entirely of transversely cut pieces (length, 5-25 $\mathrm{mm}$; diameter 2-7 mm), which are cylindrical, straight, or slightly curved; some have distinct, swollen internodes exhibiting a number of leaf and rootlet scars. The surface is a dirty light brown. The drug has a peculiar odor and a pungent bitter taste that produces numbness on the tongue.

\section{Part used}

Fruit

\section{Major chemical constituents}

Piperine and piperatine, alkaloids, tannins, phenols, coumarins, essential oil, piperlongumine, piper longuminine

\section{Cardio protective activity}

The effect of methanol extract of $P$. longum fruits was evaluated on adriamycin-induced cardiotoxicity (i.e., biochemical changes, tissue peroxidation damage, and abnormal antioxidant levels) in Wistar rats. Histopathological studies of the heart revealed degenerative changes and cellular infiltration in rats treated with adriamycin; however, pretreatment with $P$. longum reduced the intensity of these lesions. The results indicate that

P. longum offers significant protection against adrlamycin-induced oxidative stress and reduces cardiotoxicity by virtue of its antioxidant activity [12]

\section{Botanical name: Zingiber officinale}

Tamil name: Inji

Taxonomy

Kingdom: Plantae

Phylum: Magnoliophyta

Class: Liliopsida

Order: Zingiberales

Family: Zingiberaceae

Genus: Zingiber

Species: Officinale

\section{Distribution}

Zingiber officinale is possibly native to India. It is widely grown as a commercial crop in south and Southeast Asia, tropical Africa (especially Sierra Leone and Nigeria), Latin America, the Caribbean (especially Jamaica) and Australia.

\section{Description}

A perennial herb reaching up to $90 \mathrm{~cm}$ in height with a large, solid, tough rhizome, which is stout, tuberous, horizontal consisting of series of many persistent roundish joints. The roots are numerous, large, cylindrical, fleshy, thick and brittle. The leaves are alternate, distichous, narrow, subsessile $1-2 \mathrm{~cm}$ wide, sheaths long, standing away from the stem. Flowers are greenish with a small dark purple or purplish black lip, in radical spikes $3.8-7.5 \mathrm{~cm}$ long and 2.5 diameter on peduncles $15-30 \mathrm{~cm}$ long. Stem is erect, leafy, 0.6-1.2 meter in height entirely covered with leafy stem and the fruits are not seen [13].

\section{Part used}

Rhizome

\section{Major chemical constituents}

Volatile oil, gingerol, alkaloids, flavonoids, carbohydrates, proteins, glycosides, saponins, steroids, terpenoids, Aldose reductase inhibitors, curcumene, calamine.

\section{Cardioprotective activity}

Ginger is having stimulatory activity on heart muscle results, stimulated blood circulation throughout the body. The increased blood circulation is believed to stimulate cellular metabolic activity which helps to relief the cramps and tension. It also helps to reduce blood pressure and cardiac workload. Ginger is also known to possess antioxidant properties. U. Bhandari et al. has provided a clear idea about the anti-oxidant defense role against isoproterenolinduced oxidative myocardial injury in rats [14].

\section{Botanical name: Tinospora cordifolia}

Tamil name: Seenthil

\section{Taxonomy}

Kingdom: Plantae

Division: Magnoliophyta

Class: Magnoliopsida

Order: Ranunculales

Family: Menispermaceae

Genus: Tinospora

Species: cordifolia

\section{Distribution}

Tinospora cordifolia is a climbing shrub widely distributed throughout India, China, North West, and parts of South-Africa, Pakistan, Malaysia, Indonesia, Vietnam, Philippines, Thailand, Myanmar, Bangladesh, and Sri-Lanka. 


\section{Description}

Tinospora cordifolia is quite large, extensively-spreading, glabrous, dioecious, perennial deciduous climber grows on wide range of hedges and trees, typically found growing in dry deciduous forests of tropical and subtropical regions up to an altitude of $1000 \mathrm{~m}$. It produces distinct male and female flowers. Its fresh stem has a green succulent bark covered by a thin brown-bark, and the bark separates from the wood turn brown with age.

The underground roots are tubercled. Leaves 5 to $10 \mathrm{~cm}$, membranous, seven to nine veins diverging from the base, somewhat roundish to 'cordate' i.e. 'heart-shaped' (that is why the species name of the plant is 'cordifolia') with a petiole of 2.5 to $7 \mathrm{~cm}$ long. The unisexual flowers bloom in summer in conspicuous racemes often found longer than that of the leaves. Yellowish green male flowers are quite small, occur in few-flowered clusters in the axils of small subulate bracts while the female-flowers are usually borne singly (i.e. solitary) along the axis. In both male and female flowers, Sepals are 6 numbers, 3 outer ones very-small, ovate-oblong and acute while the inner 3 are larger, membranous, broadly elliptical, concave and yellowish. Distribution of T. cordifolia 6 to 7 $\mathrm{mm}$, rounded at both ends and papillose [15].

\section{Part used}

Herb

\section{Major chemical constituents}

Alkaloids include berberine, tinosporol, columbin, tinosporon, chasmanthin, tinosporic acid [16].

\section{Cardioprotective activity}

The result of the present study indicated that the prior administration of methanolic extract of Tinospora cordifolia attenuates isoprenaline-induced MI. The cardioprotective activity of Tinospora cordifolia probably related to its ability to strengthen the myocardial membrane by its membrane stabilizing activity [17].

\section{Botanical name: Asparagus racemosus}

Tamil name: Thanneervitan

\section{Taxonomy}

Kingdom: Plantae

Phylum: Entophyte

Class: Monocotyledons

Order: Liliales

Family: Liliaceae/Asparagaceae

Genus: Asparagus

Species: racemosus

\section{Distribution}

A. racemosus is distributed throughout tropical Africa, Java, Australia, India, Srilanka and Southern parts of China. It is found in the tropical and subtropical regions of India, and in the Himalayas up to an altitude of $1500 \mathrm{~m}$ above sea level.

\section{Description}

A. racemosus is a climber, climbing up to $1-3 \mathrm{~m}$ high. It is an extensively scandent spinous, much branched under shrub. Roots are numerous fusiform, succulent and tuberous (30-100 cm long and 1-2 cm thick) that are skin coloured externally and silvery white or white internally, arising as a cluster from the basal end of the stem. These roots are the part that finds use in various medicinal preparations. Stem is woody, sparsely covered with recurved spines. Leaves are reduced to small scales called as cladodes that are in tufts of 2-6 in a node, finely accuminate, falcate divaricate and constitute the main photosynthetic organs. Inflorescence is a branched raceme. The plant flowers during February-March leaving a mild fragrance in its surrounding and by the end of April, fruits can be seen with attractive red berries. Flowers are white, fragrant, solitary or fascicles have a width of 0.3-0.4 cm. Berries are globose or obscurely 3 lobed. Seeds are black in colour and hard with brittle testa [18].

\section{Part used}

Roots

\section{Major chemical constituents}

Saponins-Shatavarins

\section{Cardioprotective activity}

Coronary artery disease and atherosclerosis are due to an increase in serum lipid levels such as cholesterol and due to the generation of reactive oxygen species. A. racemosus root powder supplements decreased lipid peroxidation and caused a dose-dependent reduction in lipid profiles. The total lipids, total cholesterol and triglycerides in plasma and liver as well as plasma LDL (low-density lipoprotein) and VLDL (very low-density lipoprotein)-cholesterol decreased by more than $30 \%$ [19].

\section{Botanical name: Embelia ribes}

Tamil name: Vaaivilangam

\section{Taxonomy}

Kingdom: Plantae

Phylum: Angiosperms

Order: Ericales

Family: Primulaceae

Genus: Embelia

Species: ribes [20]

\section{Distribution}

It is an Indo-Malaysian species, reported from India, Srilanka, Singapore, Malaysia and S. China. It is found to occur throughout India in Central Himalayas, Arunachal Pradesh, Assam, Maharashtra, Andhra Pradesh, Karnataka, Kerala and Tamil Nadu. This species is globally distributed in Indo-Malaysia. Within India, it is found throughout up to an altitude of $1500 \mathrm{~m}(5000 \mathrm{ft})$.

\section{Description}

A large scandent Straggling shrub with a long slender brittle stem, It is a Climbing- 111 creeper shrub, flexible, and terete branches; bark studded with lenticels Leaves simple, coriaceous, alternate, ellipticovate-lanceolate, smooth leaves gland-dotted, short and obtusely acuminate, broad, entire perfectly glabrous. It is about 3 inch long and $1 \frac{1}{2}$ inches broad, shiny above. Petiole; $1.0 \mathrm{~cm}$ to $0.8 \mathrm{~cm}$ margined, Midrib; prominent Flowers; small, greenish yellow to whitish pink colored. In racemes at end of branches Small, globular Fruits about the size of white pepper, reddish brown to blackish. It is found in bunches. Root; brownish grey Rootlets; hairy reddish. Fruit: The fruits are brownish-black on ageing, globular to sub-globular, 2$4 \mathrm{~mm}$ in diameter, and style at apex. In a few fruits, the pedicel along with persistent calyx is present. Surface is warty, pericarp brittle, enclosing a single seed, speckled with yellowish brown or white spots. Most of the seeds are striate. Transverse section of fruit shows epicarp consisting of a single row of tabular cells of the epidermis, generally not distinct due to deposition of coloring matter.

\section{Parts used}

Berries, roots, bark

\section{Major chemical constituents}

The main component of vidanga is Embelin containing Embelic acid: 2, 5-dihydroxy-3-undecyl-1, 4-Benzoquinone and also contains christembeline, an alkaloid and resinoid and volatile oil [21].

\section{Cardioprotective activity}

Cardioprotective effect of aqueous extract of E. ribes was evaluated in a rat model having an acute myocardial infarction, induced by 
isoproterenol. E. ribes significantly decreased the heart rate, systolic blood pressure, increased levels of serum lactate dehydrogenase, serum creatine kinase and myocardial lipid peroxides and significantly increased the myocardial endogenous antioxidants levels. Pretreatment with ethanol E. ribes extract against isoproterenol (ISO)induced myocardial infarction in albino rats significantly $(\mathrm{P}<0.01)$ decreased the elevated levels of $\mathrm{LDH}$ and $\mathrm{CK}$ in serum and myocardial TBARS and increased the reduced levels of GSH, SOD and CAT in heart homogenates. Histopathological observation revealed marked protection by the extract in myocardial necrotic damage.

The results of this study provide evidence that ethanol E. ribes extract treatment enhances the antioxidant defense against ISOinduced myocardial infarction in rats and exhibits cardioprotective properties.

The protective effect of E. ribes on isoproterenol (ISO)-induced cardiomyopathy in streptozotocin (STZ)-induced diabetic rats was studied by treatment of E. ribes ethanol extract $(200 \mathrm{mg} / \mathrm{kg})$ on pathogenic $(\mathrm{STZ}+\mathrm{ISOtreated})$ rats resulted in a significant $(\mathrm{p}<0.01)$ increase in HR, blood glutathione, serum LDH, and myocardial endogenous antioxidant levels with a significant $(\mathrm{p}<0.01)$ decrease in $\mathrm{BP}$, blood glucose, HbA1C, serum CK, and myocardial TBARS levels [22].

\section{Botanical name: Andrographis paniculata}

Tamil name: Nilavembu

\section{Taxonomy}

Kingdom: Plantae

Order: Personales

Family: Acanthaceae

Genus: Andrographis

Species: paniculato

\section{Distribution}

A. paniculata is native to Taiwan, Mainland China, and India. It is also commonly found in the tropical and subtropical Asia, Southeast Asia, and some other countries including Cambodia, Caribbean islands, Indonesia, Laos, Malaysia, Myanmar, Sri Lanka, Thailand, and Vietnam. This plant is also found in different phytogeographical and edaphic zones of China, America, West Indies, and Christmas Island.

\section{Description}

Andrographis paniculata grows erect to a height of $30-110 \mathrm{~cm}(12-43$ in) in moist, shady places. The slender stem is dark green, squared in cross-section with longitudinal furrows and wings along the angles. The lance-shaped leaves have hairless blades measuring up to $8 \mathrm{~cm}$ (3.1 in) long by $2.5 \mathrm{~cm}(0.98 \mathrm{in})$. The small flowers are borne in spreading racemes. The fruit is a capsule around $2 \mathrm{~cm}(0.79 \mathrm{in})$ long and a few millimeters wide. It contains many yellow-brown seeds [23].

\section{Part used}

Roots

\section{Major chemical constituents}

Andrographolide

\section{Cardioprotective activity}

Andrographolide protects the cardiac myocytes against hypoxia/reoxygenation injury and antioxidant activity [16]

\section{Botanical name: Nelumbo nucifera}

Tamil name: Thaamarai

Taxonomy

Kingdom: Plantae

Division: Magnoliophyta

Class: Magnoliopsida
Subclass: Magnoliidae

Order: Proteales

Family: Nymphaeaceae

Genus: Nelumbo

Species: nucifera

\section{Description}

The sacred lotus is a perennial aquatic plant with rhizomes (often mistakenly called 'roots') that grow in the mud at the bottom of shallow ponds, lakes, lagoons, marshes and flooded fields. It's large, peltate (with the leaf-stalk attaching to the centre, rather than the edge) leaves rise above the water surface on 1 to $2 \mathrm{~m}$ long petioles 4-6. Lotus grows to a height of about $150 \mathrm{~cm}$, with a 3-meter horizontal spread. The leaves can be as large as $60 \mathrm{~cm}$ in diameter, while the showy flowers can be up to $20 \mathrm{~cm}$ in diameter. The fruits are a conical pod, with seeds contained in holes in the pod. Leaves are large, of both types, aerial as well as floating orbicular $20-90 \mathrm{~cm}$. in diameter. The usual length varies from 24.00 to $33.00 \mathrm{~cm}$. in case of aerial leaves and 23 to $30 \mathrm{~cm}$ in case of floating, petioles are smooth, greenish or greenish brown in color with small brown dots sometimes rough with very small, but distinct princkees, odor is distinct, fracture is fibrous. Seeds fill in the ripe carpe,white pink or pinkish-white fragrant peduncles arising from the nodes of the rhizomes, sheathing at the base, 1-2 cm long, green or blackish green, hard and stout, smooth or rough due to the presence of numerous small scattered prickles, sepals, petals and stamens are spirally arranged passing gradually one into another. The rhizomes are $60-140 \mathrm{~cm}$ long 0.5 to $2.5 \mathrm{~cm}$ in diameter. When freshly cut is exudes mucilaginous juice and show a few large cavities surrounded by several larger ones, fracture is tough and fibrous. Odor is indistinct [24].

\section{Parts used}

Flowers

\section{Major chemical constituents}

Quercetin, luteolin, alkaloids [16]

\section{Cardioprotective activity}

Neferine's antagonized arrhythmias induced by aconitine in rats, calcium chloride in mice, and coronary occlusion-reperfusion in dogs. Neferine's anti-arrhythmic effect may involve blocking human ether-à-go-go-related gene channels associated with repolarization of the cardiac activity potential [24].

Ethanolic extract of Nelumbo nucifera $(150 \mathrm{mg} / \mathrm{kg}$ and $300 \mathrm{mg} / \mathrm{kg}$ p. o once daily) pretreated-ISO administered rats maintains the levels of AST, ALT, CK, and LDH near to normal. This data suggested that N. $\mathrm{N}$. is effective cardioprotective effect at the dose of $150 \mathrm{mg} / \mathrm{kg}$ and $300 \mathrm{mg} / \mathrm{kg}$ p. o. once daily) [25].

\section{Botanical name: Allium sativum}

Tamil name: Vellaipoondu

\section{Taxonomy}

Kingdom: Plantae

Phylum: Magnoliophyta

Class: Lilopsida

Order: Liliales

Family: Liliaceae

Genus: Allium

Species: Allium sativum [26]

\section{Description}

It is an underground perennial bulb and grows up to $1.2 \mathrm{~m}(4 \mathrm{ft})$ in height. Garlic as a whole is called either head or knob. But the individual part is known as the garlic clove/bulblets, that weights $1 \mathrm{~g}$ 
(approximately). On plantation, clove matures into bulb. Therefore, garlic is a bulbous plant. The compound build is only part that is eaten and is used for medicinal purpose. Each bulb is made up of 420 cloves. Leaves of garlic are elongated, contracted and flat. The flowers are hermaphrodite in nature. They are whitish in color and are placed at the end of a stalk rising direct from the bulb. Garlic differs in size, pungency and color according to its varieties [27]

\section{Parts used}

Bulb

\section{Major chemical constituents}

Sulphur compounds, Allicin [16]

\section{Cardioprotective activity}

Disorders of the heart and the circulatory system claim more lives than any other diseases. It is the obstruction or clogging of the coronary arteries which causes more deaths than any other factors. The arteries, which supply the heart with blood and oxygen, become increasingly narrower as plaque builds up over time. When blood supply becomes restricted, a certain portion of the heart is deprived of oxygen and leads to heart attack. The two greatest means of heart disease are high blood pressure and high blood serum cholesterol levels; which are directly impacted by the therapeutic activity of garlic. The relevant role of garlic in coronary heart disease was done on rabbits and found that even preexisting atherosclerotic deposits and lesions could actually be reversed if garlic was consistently consumed [28]

\section{Botanical name: Bauhinia variegata}

Tamil name: Mantharai

\section{Taxonomy}

Kingdom: Plantae

Class`: Dicotyledone

Orde`r: Rosales

Family: Caesalpiniaceae

Genus: Bauhinia

Species: variegata

\section{Description}

Bauhinia variegata Linn. is a small to the medium sized tree with hairy branches. Leaves are phospholipid composition, inhibited activation of peroxidation, decreased phospholipase activity, prevented a decrease of $\mathrm{Ca} 2+\mathrm{ATPase}$ and $\mathrm{Ca} 2+$ binding and uptake by sarcoplasmic reticulum, and increased sarcolemmal $\mathrm{Na}+, \mathrm{K}+-$ ATPase, sarcoplasmic reticulum creatine phosphokinase. Root bark of Bauhinia variegata Linn reported steroids, saponins, tannins, poly phenolic compounds and flavonoids isolated from the different parts of Bauhinia variegata has effect as antiarrhythmic effect [30]

\section{CONCLUSION}

This review paper makes an attempt of the authors to compile a detailed outline of some cardioprotective plants used in Siddha system of medicine. The various chemical constituents and cardioprotective plants which potentiate the work on cardioprotective activity in various animal models will help the researchers to do further clinical research. Hence the review of the different herbs which could be effective and reduce the mortality of Cardio Vascular Diseases (CVDs).

\section{AUTHORS CONTRIBUTIONS}

All the author have contributed equally

\section{CONFLICT OF INTERESTS}

\section{Declare none}

\section{REFERENCES}

1. Begum S, Akhtar N. Cardioprotective effect of amlodipine in oxidative stress induced by experimental myocardial infractivity in rats. Banjladesh J Pharmacol 2007;2:55-60.
2. MacKay J, Mensah G. The atlas of heart disease and stroke. World Health Organization, Geneva; 2001.

3. Kubler W, Haass M. Cardioprotection: definition, classification, and fundamental principles. Heart 1996;75:330-3.

4. Hardman JG, Limbird LE. Goodman and gilman's the pharmacological basis of therapeutics. $10^{\text {th }}$ ed. Mc Graw-Hill Medical publishing division (NY); 2018. p. 843-65.

5. Ai AL, Bolling SF. The use of complementary and alternative therapies among middle-aged and old cardiac patients. Am J Med Qual 2002;17:21-7.

6. Nazish J, Khalil-UR-Shoukat A. Cardioprotective and antilipidemic potential of Cyprus rotundas in chemically induced cardiotoxicity. Int J Agric Biol 2012;14:989-92.

7. Ravichandra V, Hanumantharayappa B. Evaluation of cardio protective activity of galangin against doxorubicin-induced cardiomyopathy. Int J Pharm Pharm Sci 2014;6:86-90.

8. Fundter JM. Terminalia chebula Retz. In: Lemmens RHMJ, Wulijarni-Soetjipto N. Eds. Plant Resources of South-East Asia. No. 3: Dye and tannin-producing plants. Prosea Foundation, Bogor, Indonesia; 1992. p. 122-5.

9. R Rathinamoorthy, G Thilagavathi. Terminalia Chebula-review on pharmacological and biochemical studies. Int J PharmTech Res 2014;6:97-116.

10. Vidhya Unnikrishnan, K Nishteswar. Cardioprotective activities of herbal formulation of bhavamishra. IAMJ 2015;3:850-61.

11. S Suchalatha, CS Shyamadevi. Protective effect of Terminalia chebula against experimental myocardial injury induced by isoproterenol. Indian J Exp Biol 2004;42:174-8.

12. Suresh Kumar, Jitpal Kamboj, Suman, Sunil Sharma. Overview for various aspects of the health benefits of Piper Longum linn. Fruit 2011;4:134-40.

13. Kirtikar KR, Basu BD. Indian medicinal plants. $2^{\text {nd }}$ Edi. International Book Distributors, Rajpur road, Dehradun, India; 1993. p. 2435-8.

14. Ghosh AK. Zingiber officinale: a natural gold. Int J Pharma Bio Sci 2011;2:283-94.

15. Chandrayee Bhattacharyya, Goutam Bhattacharyya. Therapeutic potential of giloe, Tinospora cordifolia (Wild.) hook. f. and thomson (Menispermaceae). Int J Pharma Biol Arch 2013;4:558-84.

16. Arya Vikrant, Gupta Vivek Kumar. Review on some cardioprotective plants from Ayurveda. Int J Res Ayurveda Pharm 2011;2:80-3.

17. Neha Kesarwani, Lubna Azmi. Evaluation of cardioprotective effect of Tinospora cordifolia against isoprenaline induced myocardial infarction in rats. Int J Curr Microbiol Appl Sci 2014;3:543-55.

18. Akansha Singh, B Sinha. Asparagus racemosus and its phytoconstituents. Int J Herbal Med 2014;4:18-21.

19. Deepika Choudhary, Dimple Sharma. A phytopharmacological review on Asparagus racemosus. Int J Sci Res 2014;3:742-6.

20. Bharat Lal, Neeraj Mishra. Importance of embelia ribes: an update. Int J Pharma Sci Res 2013;4:3823-38.

21. Syed Asadulla, Ramandang, Rajasekharan. Pharmacognosy of Embelia Ribes Burm F. Int J Res Pharm Chem 2011;1:1236-51.

22. Bhandari, Uma, Ansari, M Nazam. Ameliorative effect of an ethanol extract of Embelia ribes fruits on isoproterenolinduced cardiotoxicity in diabetic rats. Pharm Biol 2009;47:669-74.

23. Md Sanower Hossain, Zannat Urbi, Abubakar Sule, KM Hafizur Rahman. andrographis paniculata (burm. f.) wall. ex nees: a review of ethnobotany, phytochemistry, and pharmacology. Sci World J 2014. Doi:10.1155/2014/274905

24. Sasikumar Dhanarasu, Awdah Al-Hazimi. Phytochemistry, pharmacological and therapeutic applications of Nelumbo nucifera. Asian J Phytomed Clin Res2013;1:123-36.

25. Shivendra Pratap Singh, Navneet Kumar Verma. Cardioprotective activity of Nelumbo nucifera rhizomes in isoproterenol induced myocardial necrosis in male wistar rats. J Chem Pharm Res 2015;7:627-42.

26. H Stavelikova. Morphological characteristics of garlic (Allium sativum L.) genetic resources collection. Information Hort Sci 2008; $35: 130-5$.

27. Sethi Neeraj, Kaura Sushila. Garlic-a pungent wonder from nature. Int Res J Pharm 2014;5:523-9. 
28. Bordia A. Effect of garlic on blood lipids in patients with coronary heart disease. Am J Clin Nutr 1981;34:2100-3.

29. Tewari Ramesh Chandra, Chaubey Suresh. Kanchnara (Bauhinia Variegata linn.): a critical review. Int J Ayurveda Pharma Res 2015;3:39-46.
30. Rajesh Kumar Sharma, Ashish Kumar Sharma. Evaluation of cardioprotective activity of aqueous and ethanolic extract of Bauhinia Variegata in cacl2 induced arrhythmia in albino rats. J Appl Pharm Sci 2013;3:169-73. 